\title{
Analysis of Factors Affecting the Achievement of Complete BasicImmunization for Babies in Weliman Public Health Center Malaka Regency
}

\author{
Oktaviana Muti ${ }^{*}$, Serlie K. A Littik ${ }^{2}$, Muntasir $^{2}$, Idawati Trisno ${ }^{2}$, Agus A. Nalle ${ }^{2}$ \\ ${ }^{1}$ Public Health Sciences Faculty Students, Post-Graduate Program, Nusa Cendana University, Kupang-85001, East Nusa Tenggara, \\ Indonesia \\ ${ }^{2}$ Public Health Sciences Faculty Lecturer, Post-Graduate Program, Nusa Cendana University, Kupang-85001, East Nusa Tenggara, \\ Indonesia
}

\author{
Article History \\ Received: 03.12.2020 \\ Accepted: 15.12 .2020 \\ Published: 21.12.2020 \\ Journal homepage: \\ https://www.easpublisher.com
}

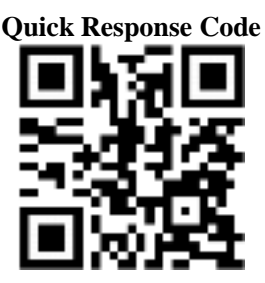

\begin{abstract}
Analysis of factors affecting the achievement of complete basic immunization for babies at the Weliman Public Health Center, Malaka was conducted to analyze the implementation of the immunization program. This research is a quantitative study using a cross sectional design. The sample in this study were mothers who had babies aged 9-12 months at Weliman Public Health Center, totaling 97 respondents and were taken using purposive sampling technique.Data analysis used simple logistic regression and multiple logistic regression. The results of the bivariate analysis showed that there was an influence of predisposing factors, namely mother's knowledge $(p=0.016)$, mother's attitude $(p=$ $0.019)$, mother's education $(p=0.001)$, and mother's occupation $(p=0.000)$. The results of the multivariate analysis test showed that there was an effect of mother's attitudes ( $p=$ $0.039)$, mother's education $(p=0.002)$, and mother's work $(p=0.008)$ on this. The variable with the highest Exp (B) value is mother's education (7,571). Factors that influence the achievement of complete basic immunizationfor babies at the Weliman Public Health Center, Malaka are mother's knowledge, mother's attitude, mother's education, mother's job. Therefore, it is necessary to make efforts to improve the quality of health services by conducting regular evaluations of health workers, holding training and increasing promotional and preventive efforts by conducting IEC for mothers and families.

Keywords: Complete Basic Immunization, Infants, Public Health Center.
\end{abstract}

Copyright (C) 2020 The Author(s): This is an open-access article distributed under the terms of the Creative Commons Attribution 4.0 International License (CC BY-NC 4.0) which permits unrestricted use, distribution, and reproduction in any medium for non-commercial use provided the original author and source are credited.

\section{INTRODUCTION}

Immunization is an effort to actively increase a person's immunity against a disease so that if one day they are exposed to the disease, they will not get sick or only experience mild illness, Indonesia Ministry of Health, 2017. Indonesia is one of the countries with a large number of children who do not get complete immunization. This situation has resulted in the emergence of PD3I Extraordinary Events (KLB) such as diphtheria, measles, and polio, and there are even children who have never received immunizations at all since birth, Indonesia Ministry of Health RI, 2019. The quality of mother and infant health services is very much determined by the management of midwifery care on an ongoing basis through a systematic problemsolving process, starting from analyzing data analysis (subjective and objective data) so that actual and potential midwifery diagnoses are obtained, problems and needs, planning, implementation to evaluation $[1$, $2]$.
Health profile data for East Nusa Tenggara (NTT) in 2018 is based on the results of the conversion of the number of infant mortality cases which fluctuated from 2014 to 2018 , in 2014 there were 1,280 cases of infant mortality with an infant conversion rate of 14 per 1000 live births, in 2015 it increased to 1,488 cases with a baby conversion rate of 10 per 1000 live births, in 2016 it decreased to 704 cases with a baby conversion rate of 7.7 per 1000 live births, and in 2018 cases increased to 1,131 with a baby conversion rate of 11.7 per 1000 live births. The increase in cases of infant mortality is partly caused by PD3I. Complete basic immunization rate for babiesin the last three years has increased, namely 2016: $69.29 \%$, 2017: $72.19 \%$ and in 2018 it increased to $79.4 \%$. Although there has been an increase in the percentage of infant IDL coverage, it is still below the 2018 Ministry of Health Restra target of $92.5 \%$ [3].

The 2018 Malaka Health Office report shows that the achievements of complete basic immunization for babies in 2018 are still below the Ministry of 
Health's Strategic Plan target, namely: 71.6\%. The percentage of the target population vaccinated, based on the antigen, were: HB0 $56.0 \%$, BCG $69.9 \%$, polio $65.1 \%$, DPT-HB-Hib $63.0 \%$ and measles $68.5 \%$. The number of cases reported due to PD3I is 1 positive case of measles and 4 suspected cases of measles [4].

The profile data of the Weliman Public Health Center in 2018 shows that the percentage of infant IDL achievement is low, namely: $41.82 \%$. Percentage of target population vaccinated, based on antigen: HB0 $78.3 \%$, BCG $85.3 \%$, polio $45.3 \%$, DPT-HB-Hib $54.4 \%$ and measles $29.0 \%$. The number of cases reported due to PD3I was 1 positive case of measles and 4 suspected cases of measles in 2018 [5]. This study aims to analyze the factors that influence the achievement of complete basic immunization for babies.

The results of Prihanti's [6] study indicate that factors affect the status of basic immunization completeness, namely predisposing factors (predisposing) age, occupation, and knowledge [6].

\section{MeTHODS}

This research is a quantitative study using a cross sectional design. The sample in this study were mothers who had babies aged 9-12 months at Weliman Public Center, totaling 97 respondents and were taken using purposive sampling technique. Data collection was carried out at the Weliman Public Health Center for one month (March-April), since the research letter was issued by the Nusa Cendana University. The data analysis used in this study was univariate, bivariate, and multivariate analysis with logistic regression. The data analysis technique used in this study was multiple logistic regression analysis. Multiple logistic regression has more than one independent variable $(\mathrm{X} 1, \ldots . ., \mathrm{Xp})$ and one dependent variable $\mathrm{Y}$ with dichotomic nominal scale.

$$
\begin{aligned}
& \text { Rumus :Y }=\operatorname{Ln}\left[\frac{\mathrm{p}}{1+\mathrm{p}}\right]=\mathrm{e}^{-\mathrm{z}} \\
& \qquad \mathrm{P}=\frac{\mathrm{y}}{1+\mathrm{p}}=\operatorname{Ln} \frac{\mathrm{p}}{\frac{1+\mathrm{p}}{1+\mathrm{p}}}=\frac{\mathrm{e}^{-\mathrm{z}}}{1+\mathrm{e}^{-\mathrm{z}}}
\end{aligned}
$$

Where $\mathrm{Z}=\beta \mathrm{o}+\beta 1 \mathrm{X} 1+\ldots .+\beta \mathrm{p} \mathrm{Xp}+\ldots .+\mathrm{e}$ for $\mathrm{a}$ theoretical model on the population whereas $\mathrm{Z}=\mathrm{bo}+$ $\mathrm{b} 1 \mathrm{X} 1+\ldots ., \mathrm{bpXp}+\ldots+\mathrm{bpXpfor} \mathrm{sample} \mathrm{statistics.}$

If the percentage of the relationship between the independent variable and the dependent variable is> $50 \%$ and the significance value is greater than 0.05 , it can be concluded that there is an effect of the achievement of complete basic immunization for babieswith predisposing factors:mother's knowledge, mother's attitude, mother's age, mother's education, mother's occupation, and vice versa.This research has received approval from the Health Research Ethics Commission issued by the Faculty of Medicine, University of Nusa Cendana Kupang on March 30, 2020.

\section{RESULT}

The results of quantitative research obtained from distributing questionnaires will then be calculated using simple logistic regression coefficients, multiple logistic regression in SPSS 26, seeing the value of the relationship between the independent variable and the dependent variable partially and simultaneously can be seen in the following table:

Table-1: Frequency Distribution of Independent Variables and Dependent Variables

\begin{tabular}{|l|l|l|}
\hline Variable & n & \% \\
\hline Complete Basic Immunization For Babies & & \\
\hline Complete & 59 & 60,8 \\
\hline Not Complete & 38 & 39,2 \\
\hline Mother's Knowledge & 76 & 78,4 \\
\hline Lack & 7 & 7,2 \\
\hline Enough & 14 & 14,4 \\
\hline Good & 76 & 78,4 \\
\hline Mother's Attitude & 21 & 21,6 \\
\hline Negatif & \multicolumn{3}{|l|}{} \\
\hline Positif & 36 & 37,1 \\
\hline Mother's Age & 61 & 62,9 \\
\hline Adults in Early <30 & 78 & 80,4 \\
\hline Adults at the End Of $\geq 30$ & 17 & 17,5 \\
\hline Mother's Education & 2 & 2.1 \\
\hline Primary Education (Elementary, Junior High, and MTs) & \multicolumn{2}{|l|}{} \\
\hline Secondary Education (High School) & 25 & 25,8 \\
\hline Higher Education (Associate Degree- Postgraduate) & 72 & 74,2 \\
\hline Mother's Occupation & $\mathbf{9 7}$ & $\mathbf{1 0 0}$ \\
\hline Have No Jobs & \multicolumn{3}{|l|}{} \\
\hline Have Jobs & 77 \\
\hline Total & \multicolumn{3}{|l|}{} \\
\hline
\end{tabular}


The results showed that of the 97 respondents (100\%), mothers who had babies with incomplete basic immunization were $59(60.8 \%)$, mothers with insufficient knowledge were $76(78.4 \%)$, respondents with negative attitudes were $76(78.4 \%)$, mothers with the age category at the end of $\geq 30$ years were 61 $(62.9 \%)$, mothers with basic education levels (Elementary, MI, Junior High and MTs) were 78
$(80.4 \%)$, and mothers who worked as much as 72 $(74.2 \%)$

Table-2 Cross tabulation of the relationship between mother's knowledge, mother's attitudes, mother's age, mother's education, and mother's occupation on the achievement of complete basic immunization for babies.

Table-2

\begin{tabular}{|c|c|c|c|c|c|c|c|c|}
\hline \multirow[t]{3}{*}{ Variable } & \multicolumn{6}{|c|}{$\begin{array}{l}\text { The Achievement Of Complete Basic Immunization For } \\
\text { Babies }\end{array}$} & \multirow[t]{3}{*}{$\begin{array}{l}P \\
\text { value }\end{array}$} & \multirow[t]{3}{*}{$\mathbf{R P}$} \\
\hline & \multicolumn{2}{|c|}{ Not Complete } & \multicolumn{2}{|c|}{ Complete } & \multicolumn{2}{|c|}{ Total } & & \\
\hline & $\mathbf{n}$ & $\%$ & $\mathbf{n}$ & $\%$ & $\mathbf{n}$ & $\%$ & & \\
\hline \multicolumn{9}{|l|}{ Mother's Knowledge } \\
\hline Lack & 42 & 43,3 & 34 & 35,1 & 76 & 100 & 0,036 & 0,460 \\
\hline Enough & 5 & 5,2 & 2 & 2,1 & 7 & 100 & & \\
\hline Good & 12 & 12,3 & 2 & 2,1 & 14 & 100 & & \\
\hline \multicolumn{9}{|l|}{ Mother's Attitude } \\
\hline Negatif & 51 & 52,6 & 25 & 25,8 & 76 & 100 & 0,019 & 3,315 \\
\hline Positif & 8 & $8,2 \%$ & 13 & 13,4 & 21 & 100 & & \\
\hline \multicolumn{9}{|l|}{ Mother's Age } \\
\hline $\begin{array}{l}\text { Adults in Early }<30 \text { years } \\
\text { old }\end{array}$ & 19 & 19,6 & 17 & 17,5 & 36 & 100 & 0,214 & 0,587 \\
\hline $\begin{array}{l}\text { Adults at the End Of } \geq 30 \\
\text { years old }\end{array}$ & 40 & 41,2 & 21 & 21,6 & 61 & 100 & & \\
\hline \multicolumn{9}{|l|}{ Mother's Education } \\
\hline Primary & 57 & 58,8 & 21 & 21,6 & 78 & 100 & 0,000 & 8,172 \\
\hline Secondary & 1 & 1,0 & 16 & 16,5 & 17 & 100 & & \\
\hline Higher Education & 1 & 1,0 & 1 & 1,0 & 2 & 100 & & \\
\hline \multicolumn{9}{|l|}{ Mother's Occupation } \\
\hline Have no Jobs & 8 & 8,2 & 17 & 17,5 & 25 & 100 & 0,001 & 0,194 \\
\hline Have Jobs & 51 & 52,6 & 21 & 21,6 & 72 & 100 & & \\
\hline
\end{tabular}

Based on Table-2 above, it could be seen partially that the variables of mother's knowledge ( $\mathrm{p}=$ 0.036), mother's attitude $(p=0.029)$, mother's education $(\mathrm{p}=0.000)$, and mother's occupation $(\mathrm{p}=$ 0.001 ) had an influence the achievement of complete basic immunization for babies. This can be seen from the significance value of the four variables which is less than 0.05. Meanwhile, the variable of mother's age had no relationship with theachievement of complete basic immunization for babies as seen from the significance value which was greater than 0.05 , namely 0.214 . The four independent variables partially have a positive and significant effect on the dependent variable.

Table-3: Multivariate Analysis of the Achievement of Complete Basic ImmunizationFor Babies

\begin{tabular}{|l|l|l|l|l|l|l|l|l|}
\hline & B & S.E. & Wald & df & Sig. & \multirow{2xp}{*}{ Ex) } & \multicolumn{2}{|l|}{ 95\% C.I.for EXP(B) } \\
\cline { 7 - 10 } & & & & & & & Lower & Upper \\
\hline Mother's Education & 1.986 & 0.614 & 10.480 & 1 & 0.001 & 7.288 & 2.190 & 24.258 \\
\hline Mother's Occupation & -1.588 & 0.537 & 8.754 & 1 & 0.003 & 0.204 & 0.071 & 0.585 \\
\hline Constant & -0.104 & 1.167 & 0.008 & 1 & 0.929 & 0.901 & & \\
\hline
\end{tabular}

Based on Table-3, it could be seen simultaneously that the variables of mother's education and mother's occupation had an influence on the achievement of complete basic immunization for babies.This can be seen from the significance value of the two variables which is less than 0.05 , namely mother's education $(\mathrm{p}=0.001)$ and mother's work $(\mathrm{p}=$ 0.003 ) with a simultaneous effect value ( $\mathrm{R}$ Square) of
0.316 or $31.6 \%$. So that it can be described in the form of a diagram as follows:

\section{DISCUSSION}

The Influence of Mother's Knowledge on the Achievement of Complete Basic Immunization for Babies

Knowledge is the result of knowing and this happens after people sense a certain object. Sensing 
occurs through the five human senses, namely: sight, hearing, smell, taste, and touch. Most of human knowledge is obtained through the eyes and ears. Cognitive Knowledge is a very important domain for the formation of one's actions (overt behavior). The level of knowledge in the cognitive domain according to the knowledge included in the cognitive domain has six levels, namely: know, comprehension, application, analysis, synthesis, and evaluation [7].

The results showed that most of the mothers lacked knowledge about basic unfantimmunization at the Weliman Public Health Center, Malaka. In theory, the better the mother's knowledge, the more complete the baby's complete basic immunizationwill be. Mothers who have less knowledge make them not know what to do with their babies, especially about immunization problems. The results of simple logistic regression analysis showed that there was an effect of knowledge on the achievement of complete basic immunization for babiesat Weliman Public Health Center, Malaka.

According to the researcher's analysis, the mother's lack of knowledge is due to the lack of information about the complete basic immunization for babiesso that the baby tends not to get the complete basic immunization. Lack of mother's knowledge can be seen from the results of the study, namely most mothers do not know about immunization, the complete basic immunization for babies, PD3I, the benefits of basic immunization, types of basic immunization, and timing of basic immunization. Mothers with low knowledge in the health center will influence the mother's actions.Mothers who have good knowledge will apply this knowledge to their babies. Mothers with good knowledge of complete basic immunizationwill provide complete basic immunizations for babies, know the types of immunizations that are important for babies, and pay attention to the right time to give these immunizations so that their babies get complete basic immunizations and avoid PD3I.

This research is also in line with research conducted by Vivi Triana [8] which shows that there is an influence between parental knowledge and giving complete basic immunization to infants. In the study, there was a significant relationship between knowledge and provision of basic immunization for infants $(\mathrm{p}=$ 0.007) with a PR value $=2.02$ (95\% CI: 1,223.36), meaning that parents who had low level of knowledge had a 2.02 times greater risk of not provide complete basic immunization to their babies rather than mothers who knowledgeable [8].

Mother's knowledge about immunization influencing the completeness of basic immunization for babies was also obtained from research by Dwiana Kartika Putri, Dian Zuiatna [9] which showed that knowledge was a factor that influenced the completeness of basic immunization for babies. Analysis of statistical tests using the Chi-square test obtained $(p=0.000)<\alpha(0.05)$, so it can be concluded that there is an effect of mother's knowledge on completeness of basic immunization in babies in the Working Area of the Satria Health Center, Tebing Tinggi in 2017 [9].

The same research was also carried out by Gita Sekar Prihanti, Mia Puteri Rahayu, M. Najib Abdullah [6] about the factors that influence the status of complete basic immunization. In the study, it was found that there were 42 babies with incomplete basic immunization status (dropout) in the X Kediri health center working area from 2015 to July 2016. In the study, it was also found that most respondents had less level of knowledge, with a significant relationship between knowledge and the complete basic immunization for babies $(\mathrm{p}=0.019)$. The knowledge variable has a 0.22 times risk $(\mathrm{OR}=0.224)$ for completeness of immunization, with a $\mathrm{CI}$ value between $0.054-0.928$ (CI range <1). This means that if a mother has good knowledge, the possibility of complete immunization will be pressed 0.22 times compared to mothers with less level of knowledge [6].

The results of the above analysis are expected for health workers, especially at Weliman Public Health Center, to increase the knowledge of mothers about complete basic immunization for babiesby conducting routine counseling on complete basic immunization for babies to the community, especially mothers who have babies at Healthcare Center, besides providing IEC to pregnant women and family members, especially husbands. regarding complete basic immunization during pregnancy checks and working with religious leaders so that during the marriage preparation course, newly married couples are given health education, one of which is about complete basic immunization for babies.

\section{The Influence of Mother's Attitude on the Achievement of Complete Basic Immunization for Babies}

Attitude is a person's closed response to a certain stimulus or object, which already involves the opinion and emotional factors concerned. The process of attitude occurs due to stimuli such as public knowledge. These stimuli stimulate the public to respond in the form of positive and negative attitudes which will eventually manifest in real action [7].

The results of the study on the attitude variable showed that most mothers had negative perceptions of complete basic immunization for babieat the Weliman Public Health Center, Malaka. Whereas in theory, mothers with a positive attitude level will participate in immunization activities regularly. Mothers who do not bring their children to health service places for immunization are the result of mothers' attitudes that do 
not understand the importance of immunization. On the other hand, mothers who bring their children to be immunized are encouraged by the attitude of mothers who understand the importance of immunization to prevent disease. The result of simple logistic regression analysis shows that there is an effect of mother's attitude on the achievement of complete basic immunization for babies at Weliman Public Health Center, Malaka.

According to the analysis of researchers, mothers who do not understand the importance of complete basic immunization for babies tend not to immunize babies because they cannot make the right decision in being certain about what to do if their baby is not immunized, because mothers think that it is not a problem whether the baby is fully immunized or not as long as the baby is not sick. Mother's negative perceptions which eventually manifested in real action where most of the babies at Weliman Public Health Center did not receive complete basic immunization.

The results of this study are in line with research conducted by Vivi Triana [8] regarding factors related to providing complete basic immunization for babies, namely in the attitude variable there is an influence between the attitudes of parents and giving complete basic immunization to infants in Kuranji District, Padang in 2015 with PR value $=1.92(95 \%$ CI: 1.16-3.19). This means that parents who have a negative attitude about immunization are at 1.92 times greater risk of not giving complete basic immunization to their babies than mothers who have a positive attitude [8].

This research is in line with research conducted by Dwiana Kartika Putri, Dian Zuiatna [9] showing that there is an effect of mother's attitude complete basic immunization for babies. Analysis of statistical tests using the Chi-square test obtained a value $(\mathrm{p}=0.004)$, it can be concluded that there is an effect of maternal attitudes on complete basic immunization for babies in the work area of Satria Public Health Care Tebing Tinggi in 2017. Mothers with negative attitudes have a greater chance of having negative behaviors in providing basic immunization to children under five while positive attitudes have a greater chance of having positive behaviors in providing basic immunizations for children under five [9].

The same research was also carried out by Wahyuni Hafid, Santi Martini, Shrimarti R Devy [10] regarding the determinants of complete basic immunization status in babies at Konang and Geger Health Centers. The results of this study showed that most mothers had a bad attitude $(84.3 \%)$ and had babies with incomplete basic immunization, and statistically there was a very strong influence between the attitudes of mothers towards complete basic immunization status in babies with a value $(\mathrm{p}=0.000)$ [11].

Therefore, it is suggested for health workers, especially at the Weliman Public Health Center, to take actions that can improve mothers' understanding of complete basic immunization for babiesso that mothers have positive attitudes and perceptions of complete basic immunizationfor babies, such as by providing counseling for mothers who have babies. Such activities can be carried out in Public Health Center andHealthcare Center, both individually and in groups, so that mothers can increase understanding and can change their attitudes to positive attitudes towards immunization, so that mothers bring babies to get complete basic immunization.

\section{The Influence of Mother's Age on the Achievement of Complete Basic Immunization forBabies}

Age is the age of an individual that is counted from birth to birthday. As you get older, the level of maturity and strength of a person will be more mature in thinking and working (Anonymous) [12].

The results showed that most of the mothers aged $\geq 30$ years did not achieve complete basic immunization for their babies at the Weliman Public Health Center, Malaka. Whereas in theory, the older the person is, the maturity level and strength of a person will be more mature in thinking and working. The results of simple logistic regression analysis showed that there was no effect of maternal age on the achievement of complete basic immunization for babies at the Weliman Public Health Center, Malaka.

The results of this study are in line with the research of Adzaniyah Isyani Rahmawati, Chatarina Umbul Wahjuni [10] about the factors that influence the complete basic immunizationin the Northern Krembangan Village, showing that there was no relationship between maternal age and complete basic immunization for babiesor children under five.The same research was also conducted by Farwah Pratiwi, Arina, Tri Rina [13] showing that there was no effect of maternal age on infant IDL completeness with a value $(p=0.536)$. From the results of the initial interviews conducted by researchers, it was concluded that there was no difference in behavior in immunizing babies on the average of respondents with a young age and those aged> 30 years due to the lack of awareness of mothers about the importance of basic immunization [10].

The results of this study contradict the theory and research conducted by Wati [14], mothers who is older have more experience and better understand the dangers of disease threats so they take disease prevention measures. Young mothers have little opportunity because they have not been exposed to much health information and do not understand the benefits of immunization for their children [14]. 
According to researchers, there is no influence between the mother's age on the the achievement of complete basic immunization for babies at Weliman Public Health Center due to other factors, namely mother's knowledge, mother's attitude, and mother's occupation where the mother is busy working so that the increase in the number of children in the family or other things causes the mother's attention to be divided and do not have time again bringing the baby to be immunized. It is hoped that, with the results of the researcher's analysis above, health workers, especially at Weliman Public Health Center, will take action to increase mother's knowledge by providing education to the community, especially for mothers with babies about the importance of complete basic immunization for babies.

\section{The Influence of Mother's Education onthe Achievement of Complete Basic ImmunizationforBabies}

Education is an important fact in an effort to improve the quality of human resources. A better level of community education can have an effect on improving health status, Ministry of Health, 2017.

The results of the research at Weliman Public Health Center showed that most mothers had primary education (Elementary, Junior High and MTs). Whereas in theory, the higher the level of education, the more complete basic immunization for babies. Based on the results of simple logistic regression analysis, it shows that there is an effect of maternal education on the achievement of complete basic immunization for babies.

According to the researchers' analysis, mothers with lack of education have less level of knowledge so they tend not to bring babies to get immunized because they don't know what the benefits of immunization are.However, this study also found that there were mothers with primary education but had babies with complete basic immunization. This is caused by another factor, namely mother's knowledge. Even though mothers at the Weliman Public Health Center have a basic level of education, there are still those who are able to obtain information related to immunization both from the media and through counseling and suggestions from other people who influence their way of thinking and finally obey to immunize their babies completely.

The results of this study are in line with the research of Miftahol Hudhah and Atik Choirul Hidajah [15] which shows that most mothers with mother's education level $\leq 9$ years or at least have graduated from junior high school / equivalent as much as $58.3 \%$. The results showed that there was a relationship between the level of maternal education and the achievement of complete basic immunization $(p=0.020)$ [15].
Another study conducted by Farwah Pratiwi [13] showed that there was a significant relationship between basic immunization status education in children under five $(p=0.005)$. From the results of interviews by researchers, it was found that mothers with low education tended to have little knowledge so that they tended not to bring their children for immunization because they did not know what the true benefits of immunization were. For example, mothers with low education level know that their children have fever after immunization, which actually prevent them to bring their children back to immunize because they thought the immunization only can hurt their children [13].

The results of the study are not in line with the research of Nur Laeli Syukuriyah, Riyanto Martomijoyo, Ade Rahmawati [16] which shows that mothers with higher educational backgrounds are less than mothers with low educational backgrounds as much as $69.2 \%$. The statistical analysis of the respondent's education level variable obtained a value of $p=0.704$, meaning that there was no significant relationship between maternal education and basic immunization for children under five in Purwajaya Village.

The results of the researcher's analysis above can be expected to be used as a reference for health workers in carrying out the immunization program. The method of providing health promotion programs in the form of counseling must be adjusted to the character of the level of education in the Weliman Public Health Center area.

\section{The Influence of Mother's Occupation on the Achievement of Complete Basic Immunization forBabies}

According to Notoatmodjo [17] forgetting about the baby's immunization schedules due to busy work is one of the reasons for the low coverage of complete basic immunization for working mothers compared to mothers who do not work.

The results showed that most mothers at Weliman Public Health Center were mothers with working status as farmers and employees. The results of simple logistic regression analysis show that there is an effect of mother's occupation on the achievement of complete basic immunization for babies at the Weliman Public Health Center, Malaka. This is in line with Green and Kreuter's [18] theory, that literally many factors influence health behavior, where the mother's social demographic (occupation) factor is one of the factors that affect the completeness of basic immunization for babies. 
According to the researcher's analysis, mothers with working status tend not to complete basic baby immunization at Weliman Public Health Center because they are busy and do not have the opportunity to immunize babies.Based on the research results, most of the mothers at Weliman Public Health Center have jobs as farmers, entrepreneurs and employees. Mothers who work as farmers are busy taking care of the fields and gardens while mothers who work as employees are also busy working outside the home so often don't have the opportunity to come to the immunization service facility because they are still working at their workplace. This is different from a mother who does not have a job who will have more opportunities to immunize her baby than a working mother.

The results of this study are in line with research conducted by Gita Sekar Prihanti, Mia Puteri Rahayu, M. Najib Abdullah [6] which shows that occupation has an effect on completeness of basic immunization. Mothers who have jobs in order to fulfill family needs (basic needs) will affect immunization activities which include the need for a sense of security and protection so that mothers prioritize work rather than taking their babies for immunizations [19, 20].

The results of other studies that are in line with this study conducted by Wulansari [21], show that mother's employment status has a significant effect but reduces the opportunity for complete basic immunization coverage. Babies of working mothers are more likely to reduce the complete basic immunization coverage than babies of mothers who do not work [21].

The results of other studies that are in line with Yuliana's research, Samsidar Sitorus [22] show that occupation affects the complete basic immunizations with a $\mathrm{p}=0.002$. The results of the research showed that mothers who work had a great chance of not getting complete basic immunization for their babies [22].

Therefore, it is advisable for health workers to carry out IEC for working mothers so that it is necessary to involve other family members in providing basic immunization to babies and cooperation between health workers and cadres in conducting home visits for babies who are not present at the healthcare center.

\section{CONCLUSION}

Based on the results of research and discussion, it can be concluded as follows: There is an influence of predisposing factors, namely: mother's knowledge, mother's attitude, mother's education, and mother's occupation on the achievement of complete basic immunization for babies at Weliman Public Health Center. Future studies are expected to collect data with more respondents from this study.

\section{REFERENCES}

1. Varney, H., Burst, H. V., Kriebs, J. M., \& Gegor, C. L. (2004). Varney's midwifery. Jones \& Bartlett Learning.

2. Boli, R. V. T., Lerik, M. D. C., Muntasir, I. F., \& Nalle, A. A. (2020). An Analysis of Continuity of Care Implementation at Tarus and Baumata Public Health Center, Kupang Regency. EAS Jurnal of Nursing and Midwefery. 2(6).

3. Dinas Kesehatan Provinsi NTT. (2019). Profil Dinas Kesehatan Povinsi NTT 2018. Dinas Kesehatan Provinsi NTT.

4. Dinas, K. K. M. (2019). Profil Dinas Kesehatan Kabupaten Malaka 2018.

5. Puskesmas, W. (2019). Profil Puskesmas Weliman 2018. D Puskesmas Weliman.

6. Prihanti, G., Rahayu, M. P., \& Abdullah, M. N. (2016). Faktor-Faktor yang Memengaruhi Status Kelengkapan Imunisasi Dasar Diwilayah Kerja Puskesmas X Kota Kediri. Saintika Medika, Jurnal Ilmu Kesehatandan Kedokteran Keluarga.

7. Notoatmodjo, S. (2012). Promosi Kesehatan dan Prilaku Kesehatan, Edisi Revisi. Jakarta. Rineka Cipta.

8. Triana, V. (2016). Faktor-faktor yang berhubungandenganpemberianimunisasi dasar lengkap pada bayitahun 2015. Jurnal Kesehatan Masyarakat Andalas. 10(2):123-135.

9. Putri, D. K., \& Zuiatna, D. (2018). Faktor Yang Mempengaruhi Perilaku Ibu terhadap Kelengkapan Imunisasi Dasar pada Bayi di Wilaya Kerja Puskesmas Satria Kota Tebing Tinggi. Jurnal Bidan Komunitas, 1(2), 104-114.

10. Adzaniyah, I. R., \& Chatarina, U. W. (2014). Faktor yang mempengaruhikelengkapanimunisasi di kelurahan Krembangan Utara. Jurnal Berkala Epidemiologi. 2(1):59-70

11. Hafid, W., Santi, M., \& Shrimarti, R. D. (2016). Faktor Determinan Status Imunisasi Dasar Legkap Pada Bayi di Puskesmas Konang dan Geger. Jurnal Wiyata, 3(1).

12. Notoatmodjo, S. (2014). Promosi Kesehatan dan Perilaku Manusia (2014 ed.). Jakarta: Rineka Cipta.

13. Farah, P. A., \& Tri, R. (2014). Faktor-Faktor Yang Mempengaruhi Ketidakpatuhan Ibu Terhadap Pelaksanaan Imunisasi Dasar Pada Balita Di Wilayah Kerja Puskesmas Siantan Tengah Pontianak.

14. Wati. (2015). Determinan Kepatuhan Ibu Dalam Mengimunisasikan Anak Usia Sekolah Di Kota Tangerang Tahun 2015. Universitas Indonesia.

15. Miftahol, H., \& Atik, C. H. (2017). Perilaku Ibu Dalam Imunisasi Dasar Lengkap Di Puskesmas Gayam Kabupaten Sumenep. Fakultas Kesehatan Masyarakat Universitas Airlangga. Surabaya. Jurnal Promkes, 5(2):167-180.

16. Nur Laeli, S., Ryanto, M., \& Ade, R. (2019). Faktor-faktor yang berhubungandenganpemberianimunisasidasar pada 
balita di Purwajaya Kecamatan Karangampel Kabupaten Indramayu Tahun 2019, Afiasi: jurnal Kesehatan Masyarakat. 4(2):70-76

17. Notoatmodjo, S. (2003). Pendidikan dan Perilaku Kesehatan. Jakarta: Rineka Cipta.

18. Green, L. W., \& Kreuter, M. W. (2005). Precedeproceed.Health program planning: an educational and ecological approach. 4th edn. New York: McGraw-Hill.

19. Purwanto, M. N. (2000). Prinsip-prinsip dan teknik evaluasi pengajaran. Remaja Rosdakarya.
20. Prihatin, R., Munir, A., \& Nurwahyuni, N. (2016). Penggunaan teknik role playing untuk mengurangi perilaku bullying siswa kelas XII MIA SMA Negeri 5 Palu. Jurnal Konseling dan Psikoedukasi.

21. Wulansari, M. N. (2019). Determinan Cakupan Imunisasi Dasar Lengkap pada Penerima Program Keluarga Harapan. Jurnal Ekonomi Kesehatan Indonesia. 4(1).

22. Yuliana, S. S. (2018). Faktor Yang Berhubungan Dengan Pemberian Imunisasi Dasar Lengkap Di Wilayah Kerja Puskesmas Medan Area. Jurnal Kesehatan Global, 1(3):137-143. 